\title{
Effect of medicinal plants on the survival of white shrimp (Penaeus vannamei) challenged with WSSV and Vibrio parahaemolyticus
}

\author{
Jesús Arturo Fierro-Coronado ${ }^{1,2}$, Antonio Luna-González ${ }^{1}$, Carlos Juventino Cáceres-Martínez ${ }^{2}$ \\ Cesar A. Ruiz-Verdugo ${ }^{2}$, Ruth Escamilla-Montes ${ }^{1}$, Genaro Diarte-Plata ${ }^{1}$ \\ María del Carmen Flores-Miranda ${ }^{3}$, Píndaro Álvarez-Ruiz ${ }^{1}$ \& Viridiana Peraza-Gómez ${ }^{4}$ \\ ${ }^{1}$ Instituto Politécnico Nacional, Centro Interdisciplinario de Investigación para el \\ Desarrollo Integral Regional, Unidad Sinaloa, Guasave, Sinaloa, Mexico \\ ${ }^{2}$ Postgrado en Ciencias Marinas y Costeras, Universidad Autónoma de Baja California Sur \\ La Paz, B.C.S., Mexico \\ ${ }^{3}$ Departamento de Estudios para el Desarrollo Sustentable de Zonas Costeras \\ Centro Universitario de la Costa Sur, Universidad de Guadalajara, San Patricio Melaque, Jalisco, Mexico \\ ${ }^{4}$ Escuela Nacional de Ingeniería Pesquera, Universidad Autónoma de Nayarit \\ San Blas, Nayarit, Mexico \\ Corresponding author: Antonio Luna-González (aluna@ipn.mx)
}

\begin{abstract}
Survival was investigated in Penaeus vannamei fed with powdered plants (PP: garlic, echinacea, ginger, and basil) and challenged with white spot syndrome virus (WSSV) and Vibrio parahaemolyticus by ingestion and immersion, respectively. PP was added to commercial feed at a concentration of 1,2 and $4 \mathrm{~g} \mathrm{~kg}^{-1}$. The infection with both pathogens was made at the same time. Shrimp fed with PP $\left(4 \mathrm{~g} \mathrm{~kg} \mathrm{feed}^{-1}\right)$ at different frequencies showed higher survival $(96.7 \%)$ as compared to the positive control group not fed with PP (6.7\%). WSSV prevalence in live and dead shrimp was similar in all treatments challenged with both pathogens varying from 33.3 to 55\%. PP protects shrimp against WSSV and V. parahaemolyticus. Therefore, further research about the effect of PP is necessary for commercial shrimp farms.
\end{abstract}

Keywords: Allium sativum; Echinacea purpurea; Ocimum sanctum; Zingiber officinale; WSSV; powdered plants

The negative impact of viral (white spot syndrome virus, WSSV) and bacterial (acute hepatopancreatic necrosis disease, AHPND) diseases on shrimp production demands continuous innovation to increase productivity (Leu et al., 2013; Tran et al., 2013; Nunan et al., 2014). Viral diseases are not curable, and there are only antibiotics to treat bacterial diseases, which cause resistance and environmental impact (Chanu et al., 2012; Medina-Beltrán et al., 2012). Wich has led to the use of natural products, such as medicinal plants, which are a good alternative in the prevention and treatment of diseases because they are deposits and sources of safe and cheap chemical products and do not generate resistance in pathogens (Chanu et al., 2012).
The plants Aegle marmelos, Cynodon dactylon, Lantana camara, Momordica charantia, Phyllanthus amarus and fucoidan extracted from Sargassum wightii showed antiviral activity against WSSV and immunostimulated Penaeus monodon (Balasubramanian et al., 2007; Immanuel et al., 2012). In this sense, Allium sativum (garlic) contains dietary fiber, 32\% sugars (included inulin), flavonoids, pectin, and the organic sulfur compounds alliin (allicin, ajoenes, vinyldithiins, and sulfides), scordinin A and B, and garlicnins (Swiderski et al., 2007; Nohara et al., 2013). Zingiber officinale (ginger) contains sesquiterpens and phenolic compounds (gingerol and shogaol) (Hasan et al., 2012). Echinacea purpurea (Echinacea) is one of the most

Corresponding editor: Mauricio Laterça 
important and well-known medicinal plants in the world. It is highly composed of alkamides, caffeic acid derivatives, and polysaccharides; however, compounds like flavonoids (quercetin, kaempferol, isorhamnetin and their free phenolic acids, including p-coumaric, $p$ hydroxybenzoic, and protocatechuic acids), amides, and alkaloids have also been isolated (Spelman \& Wetschler, 2009; Manayi et al., 2015). Ocimum sanctum (purple basil) contains volatile oils (eugenol, carvacrol, ursolic acid, linalool, limatrol, caryophyllene, and sitosterol) (Mondal et al., 2009; Pattanayak et al., 2010), phenolic compounds (apigenin, rosmarinic acid, cirsilineol, cirsimaritin, isotimusin, and isotimonin) (Yanpallewar et al., 2004; Pattanayak et al., 2010), flavonoids (orientin, vicenin, luteolin, and molludistin) (Gupta et al., 2002), tannins, and a series of sesquiterpenes and monoterpenes (bornyl acetate, b-elemene, neral, A-pinene, b-pinene, camfeno, campesterol, and stigmasterol) (Jaggi et al., 2003).

The study aimed to determine the effect of medicinal plantas on the survival of Penaeus vannamei challenged with WSSV and Vibrio parahaemolyticus by ingestion and immersion.

Shrimp were obtained from a commercial farm with the hatchery, transported, and maintained at the Centro Interdisciplinario de Investigación para el Desarrollo Integral Regional, Unidad Sinaloa. A white spot disease analysis was made in 12 shrimp, using PCR (nested PCR, Kimura, et al., 1996), to know the percentage of WSSV-infected shrimp.

Farm shrimp (5-6 g) with symptoms of white spot disease were collected to obtain an inoculum in saline solution $(2.5 \% \mathrm{NaCl})$ and a paste of macerated abdominal muscle and branchial lamella. A white spot disease analysis was made by PCR (nested and single PCR). An inoculum of $V$. parahaemolyticus was prepared according to López-León et al. (2016).

The mixture of powdered plants (PP), A. sativum (40\%), Z. officinale (20\%), E. purpurea (20\%), and $O$. sanctum (20\%) was added to commercial feed Camaronina ${ }^{\circledR}$ (Purina, 35\% protein), which was reconstituted in a meat mill, dried at room temperature with a fan for $24 \mathrm{~h}$, and stored at $4^{\circ} \mathrm{C}$. This proportion of powdered plants was based on previous works and on the cost of the plants since Echinacea is very expensive.

Before each $V$. parahaemolyticus challenge (bioassays one and two), a bioassay (4 d) was conducted to determine the $\mathrm{LC}_{50}$ (lethal concentration, 50\%) using animals weighing $528 \pm 31.7 \mathrm{mg}$ and $452 \pm 50 \mathrm{mg}$. Experimental glass aquariums $(6 \mathrm{~L})$ contained $4 \mathrm{~L}$ of filtered sea water under constant aeration. Every bioassay consisted of five treatments, each one in triplicate (30 shrimps, 10 per tank): I) control without Vibrio; II) Vibrio $\left(1 \times 10^{3} \mathrm{CFU} \mathrm{mL}^{-1}\right)$; III $)$ Vibrio $\left(1 \times 10^{4}\right.$

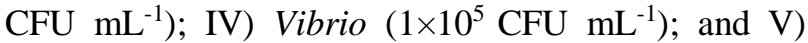

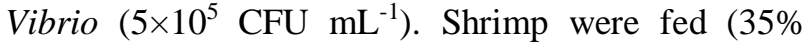
protein feed) twice daily at 09:00 and 17:00 h. Bioassays were conducted under the natural photoperiod. No cleaning of the tanks was made during the challenge period, and the temperature was maintained between 29.5 and $30.5^{\circ} \mathrm{C}$ to favor shrimp infection. Salinity was maintained at 30 . Mortality was recorded three times daily, and final data were used to calculate the $\mathrm{LC}_{50}$ using Probit analysis (Finney, 1952) with StatPlus ${ }^{\circledR} 2009$ professional 5.8.4.

The first bioassay was conducted for $10 \mathrm{~d}$ with 10 shrimp $(528 \pm 31.7 \mathrm{mg})$ per glass aquarium with $4 \mathrm{~L}$ of seawater under constant aeration. The challenge was done by adding bacteria $\left(\mathrm{LC}_{50}=15.9 \times 10^{4} \mathrm{CFU} \mathrm{mL} \mathrm{mL}^{-1}\right)$ and infected shrimp tissue (WSSV, $500 \mathrm{mg}$, low viral load) to each glass aquarium at day seven once only. The bioassay consisted of five treatments each one in triplicate (10 shrimps per tank): I) control without pathogens; II) control with WSSV + Vibrio $\mathrm{LC}_{50}$; III) PP $\left(1 \mathrm{~g} \mathrm{~kg} \mathrm{feed}^{-1}\right)+\mathrm{WSSV}+$ Vibrio $\mathrm{LC}_{50}$; IV) PP $(2 \mathrm{~g}$ $\mathrm{kg}$ feed $\left.^{-1}\right)+\mathrm{WSSV}+$ Vibrio $\mathrm{LC}_{50}$; and V) PP $(4 \mathrm{~g} \mathrm{~kg}$ feed $\left.^{-1}\right)+$ WSSV + Vibrio LC $_{50}$. Shrimp were fed (35\% protein feed) twice daily during $10 \mathrm{~d}$ (09:00 and 17:00 h) with commercial feed alone or commercial feed with PP. The bioassay was conducted under the natural photoperiod. The temperature was maintained between 29.5 and $30.5^{\circ} \mathrm{C}$. Uneaten food and waste material were removed (except days 7-10 of the challenge to avoid eliminating the vibrio) by siphoning every three days before feeding, and $50 \%$ of the water was exchanged. During the bioassay, mortality was recorded daily. Shrimp from the stock were WSSV-free.

The second bioassay was conducted for $20 \mathrm{~d}$ with 10 shrimp $(452 \pm 50 \mathrm{mg})$ per glass aquarium with $4 \mathrm{~L}$ of seawater and constant aeration. The challenge was done by adding bacteria $\left(\mathrm{LC}_{50}=6.5 \times 10^{4} \mathrm{CFU} \mathrm{mL} \mathrm{mL}^{-1}\right)$ and infected shrimp tissue (WSSV, $200 \mathrm{mg}$, high viral load) to each glass aquarium at day nine once only. The bioassay consisted of five treatments each one in triplicate (10 shrimps per tank): I) control without pathogens; II) control with WSSV + Vibrio $\mathrm{LC}_{50}$; III) PP $\left(4 \mathrm{~g} \mathrm{~kg} \mathrm{feed}^{-1}\right)$ daily + WSSV + Vibrio $\mathrm{LC}_{50}$; IV) PP $\left(4 \mathrm{~g} \mathrm{~kg} \mathrm{feed}^{-1}\right)$ every 2 days + WSSV + Vibrio LC Lo; $_{50}$ and V) PP (4 $\left.\mathrm{g} \mathrm{kg} \mathrm{feed}^{-1}\right)$ every 3 days + WSSV + Vibrio $\mathrm{LC}_{50}$. Shrimp were fed previously mentioned. The bioassay was conducted under the natural photoperiod. The temperature was maintained between 29.5 and $30.5^{\circ} \mathrm{C}$. Uneaten food and waste material were removed (except days 9-12 of the challenge to avoid eliminating pathogens) by siphoning every three days before feeding, and $50 \%$ of the water was exchanged. 


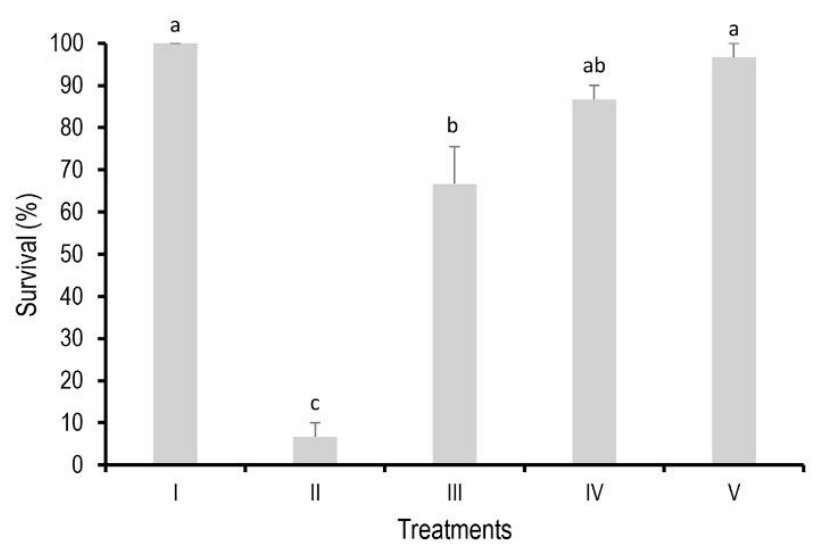

Figure 1. Survival of Penaeus vannamei fed at different concentrations of PP. Treatments: I) control without pathogens; II) control with WSSV + Vibrio LC50; III) PP $\left(1 \mathrm{~g} \mathrm{~kg} \mathrm{feed}^{-1}\right)+$ WSSV + Vibrio LC $_{50}$; IV) PP $\left(2 \mathrm{~g} \mathrm{~kg} \mathrm{feed}^{-1}\right)+\mathrm{WSSV}+$ Vibrio $\mathrm{LC}_{50}$; V) PP (4 $\left.\mathrm{g} \mathrm{kg} \mathrm{feed}^{-1}\right)+\mathrm{WSSV}+$ Vibrio LC 50 . Data are mean \pm SE (standard error). Different letters indicate significant differences $(P<0.05)$. PP: powdered plants, WSSV: white spot syndrome virus.

During the bioassay, mortality was recorded daily. Shrimps from the stock were WSSV-free.

Survival data in percentage were arcsine transformed. One-way variance analysis (ANOVA) was applied to examine the differences in survival. Where significant ANOVA differences were found, a Tukey's HSD test was used to identify these differences at $P<$ 0.05 .

In shrimp fed PP at different concentrations, the highest survival was observed in treatment IV $(96.67 \pm$ $3.33 \%)$ and the lowest in treatment II $(6.67 \pm 3.33 \%)$. The negative control group and treatments with PP showed significant differences $(P<0.05)$ as compared with treatment II in which the shrimps were only challenged with pathogens (Fig. 1).

High survival (96.7-100\%) was observed in shrimp fed PP at different frequencies. The negative control group and treatments with $\mathrm{PP}$ showed significant differences $(P<0.05)$ as compared with treatment II in which the shrimps were only challenged with pathogens. Live and dead shrimp positive to WSSV showed low viral load (nested PCR). WSSV prevalence was similar in all treatments challenged with both pathogens (Fig. 2).

Plants are a source of secondary metabolites (Chanu et al., 2012) of interest for aquaculture to prevent and treat diseases and it is known that combinations of medicinal plants can show a better biological effect than an individual medicinal plant since the bioactive compounds of each one can act in synergy (Martínez et al., 2013; Más Toro et al., 2017). For the above, we worked with a combination of garlic, ginger, basil, and

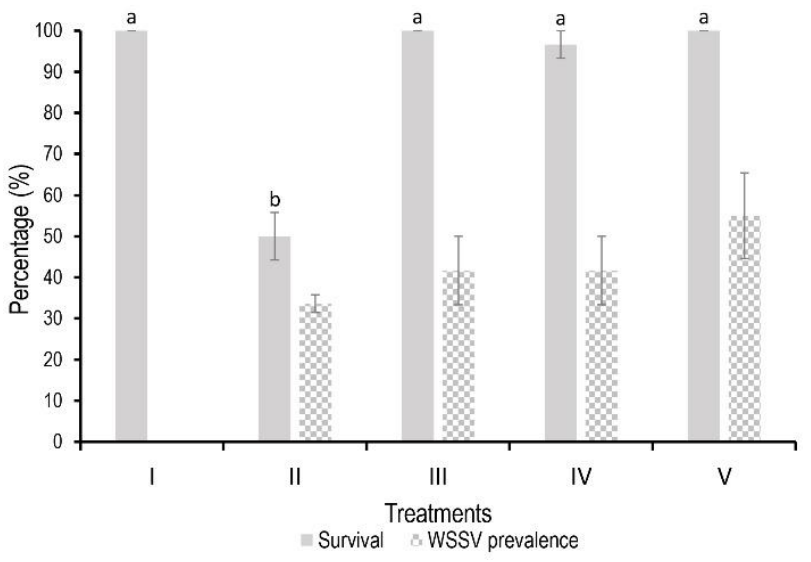

Figure 2. Survival and WSSV prevalence in Penaeus vannamei fed PP at different frequencies. Treatments: I) control without pathogens; II) control with WSSV + Vibrio $\mathrm{LC}_{50}$; III) PP (4 $\left.\mathrm{g} \mathrm{kg} \mathrm{feed}^{-1}\right)$ daily + WSSV + Vibrio $\mathrm{LC}_{50}$; IV) PP (4 $\left.\mathrm{g} \mathrm{kg} \mathrm{feed}^{-1}\right)$ every 2 days + WSSV + Vibrio $\left.\mathrm{LC}_{50} ; \mathrm{V}\right) \mathrm{PP}\left(4 \mathrm{~g} \mathrm{~kg} \mathrm{feed}^{-1}\right)$ every 3 days + WSSV + Vibrio $\mathrm{LC}_{50}$. Data are mean \pm SE. Different letters indicate significant differences $(P<0.05)$. PP: powdered plants, WSSV: white spot syndrome virus.

Echinacea to know their effect on the survival of $P$. vannamei challenged with pathogens such as $V$. parahaemolyticus and WSSV. However, it is important to mention that plants, in addition to antimicrobial and immunostimulant molecules, contain molecules such as phytic acid and tannins that can affect cultured organisms (Bairagi et al., 2002; El-Adawy, 2002; FloresMiranda et al., 2014); thus, the amount and frequency of application in the feed must be determined.

In this work, survival of shrimp challenged with WSSV and $V$. parahaemolyticus and fed with $4 \mathrm{~g} \mathrm{~kg}$ feed $^{-1}$ of PP at different frequencies was higher (50$90 \%$ ) than the survival of shrimp not fed with PP. Results were consistent with those reported by Huynh et al. (2011) who found that $P$. vannamei showed increased resistance to infection with $V$. alginolyticus and WSSV when they were immersed in seawater containing Sargassum hemiphyllum var. chinense powder and its extract. In the same way, Trejo-Flores et al. (2016) found a protective effect of Aloe vera powder ( $1 \mathrm{~g} \mathrm{~kg} \mathrm{feed}^{-1}$ every two days) in $P$. vannamei challenged with the same pathogens of this work.

Regarding WSSV prevalence in live and dead shrimp, it was similar in all treatments challenged with both pathogens, indicating that in shrimp challenged with the low viral load, mortality occurred mainly due to V. parahaemolyticus (Rubio-Castro et al., 2016), even though, Medina-Beltrán et al. (2012) and PerazaGómez et al. (2014) observed that E. purpurea and Uncaria tomentosa have antiviral (WSSV) effects that 
contribute to obtaining better survival in cultured white shrimp infected with WSSV.

Results showed that the tested PP protects shrimp against WSSV and V. parahaemolyticus. Therefore, further research about the effect of garlic, ginger, Echinacea, and basil is necessary for commercial shrimp farms.

\section{ACKNOWLEDGEMENTS}

The authors thank the Secretaría de Investigación y Posgrado del Instituto Politécnico Nacional (Mexico) for financial support (20160629). Jesús A. FierroCoronado thanks CONACYT for the doctoral fellowship (237352).

\section{REFERENCES}

Bairagi, A., Sarkar, K., Sen, S.K. \& Ray, A.K. 2002. Duckweed (Lemna polyrhiza) leaf meal as a source of feedstuff in formulated diets for rohu (Labeo rohita Ham.) fingerlings after fermentation with a fish intestinal bacterium. Bioresource Technology, 85: 1724.

Balasubramanian, G., Sarathi, M., Rajesh, S. \& Sahul, A.S. 2007. Screening the antiviral activity of Indian medicinal plants against white spot syndrome virus in shrimp. Aquaculture, 263: 15-19.

Chanu, T.I., Sharma A., Roy, S.D., Chaudhuri, A.K. \& Biswas, P. 2012. Herbal biomedicine - An alternative to synthetic chemicals in aquaculture feed in Asia. Journal of the World Aquaculture Society, 43(3): 1416.

El-Adawy, T.A. 2002. Nutritional composition and antinutritional factors of chickpeas (Cicerarietinum L.) undergoing different cooking methods and germination. Plant Foods for Human Nutrition, 57: 8397.

Finney, D.J. 1952. Probit analysis. Cambridge University, Cambridge.

Flores-Miranda, M.C., Luna-González, A., CortésEspinosa, D.V., Cortés-Jacinto, E., Fierro-Coronado, J.A., Álvarez-Ruiz, P., González-Ocampo, H.A. \& Escamilla-Montes, R. 2014. Bacterial fermentation of Lemna sp. as a potential substitute of fish meal in shrimp diets. African Journal of Microbiology Research, 8(14): 1516-1526.

Gupta, S.K., Prakash, J. \& Shrivastava, S. 2002. Validation of traditional claim of tulsi, Ocimum sanctum Linn., as a medicinal plant. Indian Journal of Experimental Biology, 40(7): 765-73.

Hasan, H.A., Rasheed A.M., Abd, B.M. \& Rasool, B.A. 2012. Pharmaceut chemical composition and antimi- crobial activity of the crude extracts isolated from Zingiber officinale by different solvents. Pharmaceutica Analytica Acta, 3: 184.

Huynh, T.G., Yeh, S.T., Lin, Y.C., Shyu, J.F., Chen, L.L. \& Chen, J.C. 2011. White shrimp Litopenaeus vannamei immersed in seawater containing Sargassum hemiphyllum var. Chinense powder and its extract showed increased immunity and resistance against Vibrio alginolyticus and white spot syndrome virus. Fish and Shellfish Immunology, 31: 286-296.

Immanuel, G., Sivagnanavelmurugana, M.I., Marudhupandia, T., Radhakrishnanb, S. \& Palavesama, A. 2012. The effect of fucoidan from brown seaweed Sargassum wightii on WSSV resistance and immune activity in shrimp Penaeus monodon (Fab). Fish and Shellfish Immunology, 32: 551-564.

Jaggi, R.K., Madaan, R. \& Singh, B. 2003. Anticonvulsant potential of holy basil, Ocimun sanctum Linn, and its cultures. Indian Journal of Experimental Biology, 41: 1329-1333.

Kimura, T., Yamano, K., Nakano, H., Momoyama, K., Hiraoka, M. \& Inouye, K. 1996. Detection of penaeid rod shaped DNA virus (PRDV) by PCR. Fish Pathology, 31: 93-98.

Leu, J.H., Lin, S.J., Huang, J.Y., Chen, T.H. \& Lo, C.F. 2013. A model for apoptotic interaction between white spot syndrome virus and shrimp. Fish and Shellfish Immunology, 34: 1011-1017.

López-León, P., Luna-González, A., Escamilla-Montes, R., Flores-Miranda, M.C., Fierro-Coronado, J.A., Álvarez-Ruíz, P. \& Diarte-Plata, G. 2016. Isolation and characterization of infectious Vibrio parahaemolyticus, the causative agent of AHPND, from the whiteleg shrimp (Litopenaeus vannamei). Latin American Journal of Aquatic Research, 44(3): 470-479.

Manayi, A., Vazirian, M. \& Saeidnia, S. 2015. Echinacea purpurea: pharmacology, phytochemistry and analysis methods. Pharmacognosy Reviews, 9(17): 63-72.

Martínez, Y., Martínez, O., Liu, G., Ren, W., Rodríguez, R., Fonseca, Y., Olmo, C., Isert, M., Ginarte, R., Valdivié, M. \& Martin, C. 2013. Effect of dietary supplementation with Anacardium occidentale on growth performance and immune and visceral organ weights in replacement laying. Journal of Food, Agriculture and Environment, 13(3-4): 1352-1357.

Más Toro, D., Martínez, Y., Rodríguez, R., Pupo, G., Rosabal, O. \& Olmo, C. 2017. Preliminary analysis of secondary metabolites in mixed powders of leaves of medicinal plants. Revista Cubana de Plantas Medicinales, 22(1): 1-9. 
Medina-Beltrán, V., Luna-González, A., FierroCoronado, J.A., Campa-Córdova, A.I., Peraza-Gómez, V., Flores-Miranda, M.C. \& Gutiérrez-Rivera, J.N. 2012. Echinacea purpurea and Uncaria tomentosa reduce the prevalence of WSSV in witheleg shrimp (Litopenaeus vannamei) cultured under laboratory conditions. Aquaculture, 358: 164-169.

Mondal, S., Mirdha, B.R. \& Mahapatra, S.C. 2009. The science behind sacredness of tulsi (Ocimum sanctum Linn.). Indian Journal of Physiology and Pharmacology, 53: 291-306.

Nohara, T., Fujiwara, Y., Ikeda, T., Murakami, K., Ono, M., Nakano, D. \& Kinjo, J. 2013. Cyclic sulfoxides garlicnins B2, B3, B4, C2, and C3 from Allium sativum. Chemical and Pharmaceutical Bulletin, 61(7): 695-699.

Nunan, L., Lightner, D., Pantoja, C. \& Gómez-Giménez, S. 2014. Detection of acute hepatopancreatic necrosis disease (AHPND) in Mexico. Diseases of Aquatic Organisms, 11: 84-86.

Pattanayak, P., Behera, P., Das, D. \& Panda, S.K. 2010. Ocimum sanctum Linn. A reservoir plant for therapeutic applications: an overview. Pharmacognosy Reviews, 4: 95-105.

Peraza-Gómez, V., Luna-González, A., González-Prieto, J.M., Fierro-Coronado, J.A. \& González-Ocampo, H.A. 2014. Protective effect of microbial immunostimulants and antiviral plants against WSSV in Litopenaeus vannamei cultured under laboratory conditions. Aquaculture, 420-421: 160-164.

Rubio-Castro, A., Luna-González, A., Álvarez-Ruiz, P., Escamilla-Montes, R., Fierro-Coronado, J.A., LópezLeón, P., Flores-Miranda, M.C. \& Diarte-Plata, G. 2016. Survival and immune-related gene expression in Litopenaeus vannamei co-infected with WSSV and Vibrio parahaemolyticus. Aquaculture, 464: 692-698.

Received: 20 February 2018; Accepted: 11 February 2019
Spelman, K. \& Wetschler, M.H. 2009. Comparison of alkylamide yield in ethanolic extracts prepared from fresh versus dry Echinacea purpurea utilizing HPLCESI-MS. Journal of Pharmaceutical and Biomedical Analysis, 49: 1141-1149.

Swiderski, F., Dabrowska, M., Rusaczonek, A. \& Waszkiewicz-Robak, B. 2007. Bioactive substances of garlic and their role in dietoprophylaxis and dietotherapy. Roczniki Państwowego Zakładu Higieny, 58(1): 41-46.

Tran, L., Nunan, L., Redman, R.M., Mohney, L.L., Pantoja, C.R., Fitzsimmons, K. \& Lightner, D.V. 2013. Determination of the infectious nature of the agent of acute hepatopancreatic necrosis syndrome affecting penaeid shrimp. Diseases of Aquatic Organisms, 105: 45-55.

Trejo-Flores, J.V., Luna-González, A., Álvarez-Ruíz, P., Escamilla-Montes, R., Peraza-Gómez, V., DiartePlata, G., Esparza-Leal, H.M., Campa-Córdova, A.I., Gámez-Jiménez, C. \& Rubio-Castro, A. 2016. Protective effect of Aloe vera in Litopenaeus vannamei challenged with Vibrio parahaemolyticus and white spot syndrome virus. Aquaculture, 465: 60-65.

Yanpallewar, S.U., Rai, S., Kumar, M. \& Acharya, S.B. 2004. Evaluation of antioxidant and neuroprotective effect of Ocimum sanctum on transient cerebral ischemia and long term cerebral hypoperfusion. Pharmacology Biochemistry and Behavior, 79: 155164. 